\title{
Yi-Ping Ong \\ Poetic Criticism and the Work of Fiction: Goethe, Joyce, and Coetzee
}

It is a hot June day in Dublin, mid-afternoon. A young, would-be, but as yet unknown poet locks horns with his elders in the age-old fight for dominance. More of a skirmish than a flat bid to wrest command from the heads of the pack: this is how they see it. They keep his forays in check with nudges and nips, but otherwise they tolerate him.

We begin in the middle of things. A dust-cloaked office of the National Library. The Director is holding court: "And we have, have we not, those priceless pages of Wilhelm Meister. A great poet on a great brother poet” (Joyce 1986, 151). On he drones, dull notes creaking in the dim air, before he is called away by his work. As soon as he leaves, the young poet takes his shot: "Monsieur de la Palice [...] was alive fifteen minutes before his death" (151). A jeer like this from a mere underling, no matter how light, will not be let to stand. Instantly a sharp voice cracks back with "elder's gall”: "Have you found those six brave medicals [...] to write Paradise Lost at your dictation? The Sorrows of Satan he calls it" (151). This last aside is directed not to the young man, but to a fellow elder. Taking up his cue, the other joins in: "All these questions are purely academic [...]. I mean, whether Hamlet is Shakespeare or James I or Essex. [...] Art has to reveal to us ideas, formless spiritual essences. [...] All the rest is the speculation of schoolboys for schoolboys" (151). The challenge of youth to the authority of the elders is dispatched.

This opening frames the episode of Joyce's Ulysses (1918) that is best known for Stephen Dedalus's pyrotechnic and at times bizarrely far-fetched account of how to read Shakespeare's Hamlet. Many critics take his reading as a veiled guide to how Joyce himself intends Ulysses to be read. Falling exactly at the midpoint of the novel, there is no question that the episode is crucial. But if Joyce had wanted to highlight Stephen's theory of art as a key to his own creation, why did he stage it like this - as part of an academic pissing contest?

If we look back, to Goethe's execution of a similar scene in Wilhelm Meister's Apprenticeship (1795-1796), and forward, to another scene in Coetzee's Elizabeth Costello (2003), we might discover further clues. All three texts exemplify what Schlegel calls, in his essay "On Goethe's Meister" (1798), "poetic criticism”: a work of art that "come[s] into being when a poet in full possession of his powers contemplates a work of art and represents it in his own” (Schlegel 2003, 281). Schlegel is here describing the sections of Wilhelm Meister's Apprenticeship between Book 4, chapter 13 and Book 5, chapter 12 that contain Wilhelm's elaboration upon and re-staging of Shakespeare's Hamlet. These are the same pages of Goethe's novel that Joyce's episode alludes to at its opening - an early hint that Joyce will set his occasion for poetic criticism beside Goethe's. Both texts contain a reading of Hamlet. Both feature 
Hamlet-like protagonists who represent themselves to others in and through the act of reading Shakespeare's play. Finally, in Coetzee's novel, although the performance of Elizabeth Costello focuses on Kafka's ape and not on the Prince of Denmark, Costello herself is a novelist whose claim to fame lies in her re-writing of Joyce's Ulysses from the point of view of Molly Bloom.

How should we read these loosely concatenated texts of poetic criticism? This question is complicated by the fact that, in all three cases, the crucial act that establishes the work as an instance of poetic criticism is carried out by a fictional character. Wilhelm's production of Hamlet, Stephen Dedalus's dazzling performance in the library, and Elizabeth Costello's speech on Kafka: all embody Schlegel's claim that "[p]oetic criticism does not act as a mere inscription, and merely say what the thing is" but rather "want[s] to represent the representation anew, and form once more what has already been formed" (Schlegel 2003, 281). These exemplary instances of poetic criticism interpret the texts they represent by re-enacting the dynamics found in these texts. Yet these acts of poetic criticism are not stand-alone works. Each is represented within the compass of a larger narrative, one that stages the making of the character-qua-critic as well as the conditions surrounding and inflecting their key performance. Time and time again, the art of poetic criticism accomplishes itself by way of a novelistic form that embeds an act of critical response to another work of art within the narrative of a central figure's life. What do these fictions of the lives of critics tell us about the form and meaning of poetic criticism?

From its origin in "On Goethe's Meister," the concept of poetic criticism is intertwined with the attempt to reorient the purpose and meaning of literary criticism. Schlegel's essay marks a seminal turn in Romantic literary history, when the critic breaks free from his traditional role as "a judge who applied neoclassical aesthetic standards, derived most notably from Aristotle and Horace, to the understanding and assessment of a work of art” (Norman 2018, 196). Schlegel - and, after him, Novalis, Schleiermacher, and Tieck - reenvisions the act of criticism as intimately bound up with the self-understanding of the literary work. Criticism amplifies, reflects, and intensifies the self-reflexive understanding that is internal to the individual work of art, and as such it must itself assume a "mode of literary self-knowledge" (204). It must become, in Schlegel's term, poetic. In my interpretation of these texts of poetic criticism, what emerges is a form of criticism as critique: criticism qua investigation of the nature and limits of self-reflection. This self-understanding is portrayed in and through the protagonists who engage in acts of literary criticism within the work of fiction. In Goethe, Joyce, and Coetzee, the fictional critic encounters a profound form of self-knowledge that is not solely generative, but also potentially destructive. The act of criticism does not, as Schlegel would have it, merely amplify, reflect, and raise self-understanding to a higher power. It also deflects, avoids, and disavows, defending the critic from the danger and pain that is inherent in knowing him or herself. This ambivalent tension is revelatory not only of the nature of criticism, but also of the structure of fictions that would seek to portray it. 
In this essay, I seek to renew our understanding of Schlegel's account of poetic criticism by re-embedding the characterological act of criticism within the more prosaic frame in which it is originally represented. The narratives of Goethe, Joyce, and Coetzee all draw attention to the conditions and motivations that underlie these various performances. Key aspects of the act fall away if we attempt to theorize poetic criticism in isolation from its fictional context. The frame of fiction opens up new questions about why figures such as Wilhelm Meister, Stephen Dedalus, and Elizabeth Costello might seek to interpret and re-enliven literary works. These questions in turn connect the form of poetic criticism with deeper currents and tensions at play in the fictions themselves. They reveal the inner conflicts that animate characterological acts of criticism, and illuminate the power and significance of these acts anew.

\section{Goethe}

The question of how to describe the instance of poetic criticism within its original fictional context straightaway raises an important problem, namely, how to circumscribe the boundaries of the critical act. Is it limited to the character's own act of interpretation and re-presentation of another work of art? Or is it the text's representation of this act, and if so, does the significance of the act ripple outward to other seemingly unrelated episodes, so that a full consideration of its meaning would require us to trace its implications throughout the novel as a whole? Finally, does the inherently metafictional structure of the act attempt to breach the implicit boundedness of the work, and implicate the reader of the text in a deliberate way? These overarching questions frame the problem at hand. Setting them aside for the time being, however, let us turn to the chief paradigm of poetic criticism in Schlegel's seminal text. At the heart of his discussion lies the extended subplot of Wilhelm Meister's Apprenticeship, comprising over a quarter of the novel, in which the protagonist not only presents extended interpretations of Shakespeare's Hamlet, but also produces and acts in his own version of the play. Wilhelm is frankly obsessed with Shakespeare's genius, pouring his heart and soul into scrutinizing the intentions of the playwright, the structure of the play, and the inner life of Hamlet. He lives and breathes the play to the point that the reality of everything else in his life falls away. Indeed, it is at this juncture that Wilhelm makes a decisive commitment to devote his life to the theater.

The narrative building up to this climax, however, sheds a somewhat different light on the state of mind in which Wilhelm first encounters Hamlet. Shakespeare does not appear in Wilhelm's life by chance. He is planted there by Jarno, an older man upon whom Wilhelm has projected his craving for mentorship and guidance. The novel portrays this yearning for approval and direction as naïve and indiscriminate. Wilhelm desires recognition from just about anyone who presents himself to be better than those around him. When a prince arrives at the baron's castle where 
Wilhelm's troupe is performing, Wilhelm immediately seizes the opportunity to ingratiate himself with a potential patron. The scene of their encounter stages an early act of literary criticism that is purely instrumental, deployed solely for the purposes of self-advancement:

\begin{abstract}
Wilhelm had been advised to praise Racine, the prince's favorite dramatist, when an appropriate opportunity presented itself, and thereby put himself in the prince's good graces. He found such an occasion one afternoon, when he had been summoned to appear with the others, and the prince asked him whether he too had studied the great French dramatists. Wilhelm said that he had. He did not notice that the prince had already turned to speak to someone else, without waiting for an answer. Almost interposing himself, he claimed the prince's attention by declaring that he had indeed a very high opinion of French drama and had read its masterpieces with great appreciation; and he had been delighted to hear that the prince paid great respect to the talents of a man like Racine. "I can well imagine," he went on to say, "that persons of noble station will appreciate an author who portrays so excellently and correctly the circumstances of high social rank." (Goethe 2016, 475)
\end{abstract}

Here follows a lengthy and fawning monologue on Racine's portrayal of " 'the gods of this earth," “"kings adored by whole nations, courtiers envied by multitudes” (476). Wilhelm concludes his paean by noting, “The report that Racine died of grief because Louis XIV showed his dissatisfaction by no longer looking at him - that to me is the key to all his works. It was impossible for such a talented writer, whose whole life, and his death, depended on the eyes of a king, not to write plays worthy of the admiration of a king - and of a prince”" (476). By this point, needless to say, the prince is no longer looking at Wilhelm. But Wilhelm persists. Interpreting Racine through the lens of his own desperate bid for royal attention, Wilhelm performs his critical admiration of the poet as an act of obsequious flattery to the greatness of his audience, who is in turn cast as the "'prince”" to Wilhelm's “"talented writer." The reading of Racine becomes a means of rendering his own self legible to another.

It is at this moment that Jarno, who just so happens to have overheard the entire speech, pulls Wilhelm aside and demands, “'Have you never seen a play by Shakespeare?”' (476) Wilhelm admits that he has not. The playwright's dubious reputation is, he goes on to confess, a reason to keep avoiding him: "“what I have heard about his plays has not made me eager to know more about such strange monstrosities"” (476). Cautioning him not to "'take offense"” at what he reads, but rather to rely on his “'own true judgment," Jarno sends him the plays (476).

When Jarno and Wilhelm meet again, Wilhelm hastens to thank him for his role in "providing him with such an experience" (484). Jarno expresses pleasure with himself for his pedagogical insight and with Wilhelm for having the sensibility to appreciate Shakespeare, while Wilhelm expresses his admiration of Shakespeare in ever more effusive and ardent terms, assuring Jarno that he has been as deeply moved by the poet as the older man had hoped.

"I cannot remember a book, a person, or an event that has affected me as deeply as these wonderful plays that you so kindly brought to my attention. They seem to be the work of some spirit 
from heaven that comes down to men and gently makes them more acquainted with themselves. They are not fictions! One seems to be standing before the huge open folios of Fate in which the storm winds of life in all their turbulence are raging, blowing the pages back and forth. I am so astonished by the forcefulness and tenderness, the violence and the control of it all, that I am completely beside myself and long for the time when I will be able to continue reading." (484)

“"Bravo!” declares Jarno at the end of Wilhelm's speech: “that's just what I wanted; and the results that I hoped for will not be long in coming”" (484). Both play their roles to perfection: caring yet superior guide, impassioned yet solicitous pupil.

Their exchange sets into sharp relief the lived context of Wilhelm's first response to Shakespeare. Having longed for the favor and esteem of Jarno from the moment he laid eyes on him, he is finally in a position to get the attention he seeks. His success in doing so is confirmed without delay. Jarno, reassured and perhaps flattered by Wilhelm's reaction to his favorite playwright, affirms his mentorship of the young man by making him a promise of future advancement: "iif you are prepared to put your talents and abilities at our service [...] then I would have an opportunity to put you in a position which you will not regret having occupied for a time"' (485). Wilhelm is elated. His dreams of bringing his innermost yearnings to fruition in the world seem at last to be within reach.

Schlegel does not remark upon these details of the narrative frame surrounding Wilhelm's reading of Shakespeare. Insofar as the scene provides one of the most direct articulations of Shakespeare's value and significance within the novel as a whole, however, it bears further scrutiny. By framing Wilhelm's encounter with Shakespeare in light of his relation to Jarno, and furthermore ironizing this encounter by closely juxtaposing it with his praise of Racine to the prince, mundane and banal motives for reading a work of art in a particular way at a particular time are allowed to surface. The human situation of the critic is foregrounded. Wilhelm's reading of Shakespeare appears to emerge as much out of his desperate need for guidance and admiration as it does from any sort of spontaneous, deep, or disinterested love for the work itself. Shakespeare is a means for uniting Jarno and Wilhelm. As soon as Jarno has declared his mentorship of Wilhelm, Shakespeare drops away and the real subject of their discussion emerges: "Wilhelm, extremely grateful for this, now felt in the mood to tell his friend and benefactor his whole life story" (485). Thus Wilhelm's reading of Shakespeare opens inevitably into the life story of Wilhelm, which of course the novel tells better than Wilhelm could ever tell himself.

Why does Goethe's luminous act of poetic criticism congeal around the dull kernel of Wilhelm's personal ambition? Without casting any suspicion on Goethe's use of Shakespeare, which relies on a complex metafictional staging of the relation between mimesis and existence, it is fair to say that Wilhelm's use of Shakespeare in 
this initial encounter is somewhat less subtle. ${ }^{1}$ Wilhelm appears entirely to believe, or to have convinced himself, in the transformative powers of Shakespearean plays. But if Jarno had asked him to read any number of playwrights, his response would no doubt have been as adulatory. Just as in his previous encounter, in which he "would gladly have gone on talking and proved to the prince that he had read the prince's favorite poet with profit and emotional involvement" (476), so too would he have generated a response to any poet marked as Jarno's favorite in the terms that he thinks Jarno would wish to hear. What might appear as an ardent, spontaneous critical response when taken in isolation is hence revealed by the narrative frame to be highly conditioned by the structural position of the critic.

The trope of self-advancement continues to figure prominently in the scenes that stage Wilhelm's extended commentary on and performance of Hamlet. His early identification with the role of Hamlet appears to arise from the same desire to affiliate himself with nobility. In his reconstruction of Hamlet's formative years prior to the death of his father, Wilhelm lays inordinate stress on the marks of Hamlet's aristocracy:

"This sensitive, noble scion, this flower of kingship, grew up under the immediate influences of majesty; concepts of right and of princely dignity, the sense of what is good and what is seemly, developed in him simultaneously with an awareness of being born into high station. He was a prince, he was born a prince, and he was desirous of ruling so that good men should be unimpeded in the exercise of goodness. Winsome in appearance, courteous by nature, pleasing by temperament, he was fashioned to be a model of youth and a delight for everybody." (500)

The fact that Wilhelm himself desires to achieve and to be regarded in terms of this noble ideal is made clear by the letter that Wilhelm writes to Werner, in the chapter immediately preceding the episodes in which he embarks on the production of Hamlet in earnest. In his letter, Wilhelm lays out his view of the differences between the nobleman and the burgher. For the nobleman, the full development and expression of personality is in harmony with the public nature of his role, whereas for the burgher, personal development is deformed by the necessity of developing his talents and knowledge for material profit. Explaining his choice to become an actor, Wilhelm writes to Werner: "I have an irresistible desire to attain the harmonious development of my personality such as was denied me by my birth [...]. On the stage a cultured human being can appear in the full splendor of his person, just as in the upper classes of society. There, mind and body keep step in all one does, and there I will be able simultaneously to be and to appear better than anywhere else"' (547548). ${ }^{2}$ The letter elides a crucial fact. The newly inherited fortune that makes Wil-

1 For an account of the metafictional significance of Goethe's representation of acting in the production of Hamlet, see Pirholt 2012, 46-50.

2 Christian Garve's Über die notwendigen Grenzen beim Gebrauch schöner Formen (1792), cited in a footnote of Schiller's 1795 essay On the Necessary Limits of the Beautiful, especially in the Presentation of Philosophical Truths, is considered by scholars to have been a probable source for "Goethe's treat- 
helm's new career possible derives entirely from the bourgeois labor of his dead father.

This, then, is the context in which Wilhelm pursues his readings and re-staging of Hamlet. Believing that inner refinement of spirit and taste will enable him to transcend the bonds of class identity, he cannot admit that he is tied to a profession dependent upon noble patronage, let alone funded by the wealth of a social class that he despises. Wilhelm is in a bind. He cannot be who he wants to be. But he cannot stop himself from wanting to be it. His inner conflict, revolving around issues of selfrealization and external determination, in turn inflects his reading of Shakespeare's play. Wilhelm's Hamlet is too pure for actuality, beset by a destiny he cannot control. Like the prince of his imaginative reconstruction, Wilhelm is a vulnerable young man who doesn't quite know how to carve a path for himself in the world. His dependence on others does not square with his aspiration to be an artist, free, transcendent of petty need. What he needs to work out is how to bypass this paradox of his situation - namely, the requirement that, on the one hand, he perform himself as totally free and disengaged from the world (recall Jarno's directions to Wilhelm on how to read Shakespeare: "'you could not employ your time better than by disassociating yourself from everything else and, in the solitude of your own room, peering into the kaleidoscope of this unknown world'" [476]), and that, on the other hand, he simultaneously come to terms with the reality of being conditioned by his fundamental dependency. This paradox, which eventually comes to embody the central conflict of the Bildungsroman between striving for autonomy and acceptance of heteronomy, is not here resolved by what Franco Moretti calls the "interiorization of contradiction" (Moretti 1987, 10) but rather by its exteriorization in drama.

Wilhelm's reading of Hamlet's personality discloses a further aspect of his psychology that has not been widely emphasized by previous critics. Wilhelm is often taken to be describing himself when he sets out "the key to Hamlet's whole behavior"' (Goethe 2016, 518). But what, exactly, is this key? When Wilhelm elucidates the “"fine, pure, noble and highly moral person," who "'devoid of that emotional strength that characterizes a hero, goes to pieces beneath a burden that it can neither support nor cast off," it is not immediately clear what his own burden might be. Indeed, the burden that he contends with throughout the novel is not presented in the form of any weighty external responsibility towards others, but rather in the knowledge of who he is: a knowledge that he cannot avow without imploding the fragile structure of his very self. As in Shakespeare's Hamlet, the "'oak tree planted in a precious pot which should only have held delicate flowers"” must be controlled, mastered, and overcome by the greater vessel of the work of art that surrounds and contains it, while at the same time exposing via the character life it portrays its own vulnerability to the power and force of what has taken root in it.

ment of the role that art and the aesthetic might play in the attempt of the Bürger to rise in the sociocultural scale” (Wilkinson and Willoughby 1968, 103). 
The nature of poetic criticism is hence inextricably linked to the nature and limits of the self-understanding that the work of art can tolerate within itself. " $H i s$ feeling of insignificance,"” says Wilhelm of Hamlet, “'never leaves him”” (517). The solution that Wilhelm arrives at is embodied in every line of his interpretation and reenactment of Hamlet. In the act of re-writing and acting, thus dying, within the play, he solves the dilemma of whether to be Hamlet or Shakespeare by being both. He realizes his childhood dream of being in the play and outside of it at once, splitting his desires for total control and total immersive transport, shielding himself from the compromises and banality of life that the narrative in which he is embedded shows all too readily. Is his attempt at self-deliverance successful? Perhaps that is the wrong question. At the close of Book V, after the all-consuming production of Hamlet is staged, a fire breaks out in the house where he is living, an actress dies of a broken heart, and Wilhelm sets off on new adventures.

\section{Joyce}

Seen in light of the larger narrative frame that surrounds it, it is difficult to understand how Wilhelm's reading of Shakespeare might be attributed to the novel's author in any straightforward way. Yet this was the dominant view throughout the nineteenth century, and it is announced as such in the opening of the library scene of Joyce's Ulysses. The episode begins with an unnamed voice uttering the lines we have already quoted: "And we have, have we not, those priceless pages of Wilhelm Meister. A great poet on a great brother poet” (Joyce 1986, 151). The speaker who invites us to see Wilhelm as articulating Goethe's own stance on Hamlet is significantly not Stephen Dedalus, but rather Thomas Lyster, director of the National Library of Ireland in Dublin between 1895 and 1920. Along with John Eglinton, born William Kirkpatrick Magee and anointed by Yeats as "our one Irish critic," and George William Russell, a "prophet, poet, philosopher, artist, journalist, economic theorist" (Gifford and Seidman 2008, 35) known as AE, his is a voice of established authority throughout the episode. These titans, gatekeepers of Ireland's literary scene, mark their turf with ease. The young poet must be subdued - always with laughter and wit, for a light touch shows mastery - but nonetheless, made to know his place in the hierarchy.

The scene in the library thus reveals that Stephen must deliver his famous interpretation of Shakespeare between the gaps of another conversation, one from which he is left out. His audience is more preoccupied with displaying their own intelligence and bolstering one another's egos than they are with paying heed to a young upstart. Stephen is time and again made conscious of his exclusion. As they natter away about their gatherings - this evening at George Moore's house to celebrate the work of new poets, the Hermetic Society on Thursday - they hardly even notice that he is there, much less wanting to be recognized. They single out others of his generation for praise and advancement, all the while overlooking him: 
Young Colum and Starkey. George Roberts is doing the commercial part. Longworth will give it a good puff in the Express. O, will he? I liked Colum's Drover. Yes, I think he has that queer thing genius. Do you think he has genius really? Yeats admired his line: As in wild earth a Grecian vase. Did he? I hope you'll be able to come tonight. Malachi Mulligan is coming too. Moore asked him to bring Haines. (Joyce 1986, 158)

Stephen thinks to himself as he listens to them: "Cordelia. Cordoglio. Lir's loneliest daughter" (158). Cordelia, King Lear's dispossessed youngest daughter; Cordoglio, Italian for "deep sorrow"; and Fionnuala, daughter of the Irish sea god, Lir, whose place was usurped by his son: this net of allusions places Stephen in a constellation of loss, tragic rivalry, and exclusion (Gifford and Seidman 2008, 215).

Stephen feels that his genius, such as it may be, is unrecognized by his audience. But the scene draws our attention to something else. What is at stake for him in the library is not a purely intellectual need for esteem, but something much more visceral: the need of a pup to be chosen and mentored by the alphas, so as to ensure his survival and the continuance of his progeny. In his case, the offspring are intellectual: "Coffined thoughts around me, in mummycases, embalmed in spice of words. [...] And I heard the voice of that Egyptian highpriest" (Joyce 1986, 159). The walls of the National Library that surround him are a stark reminder of what it means to exist in this world, a literary world into which he wishes to gain entrée. Here each thought that survives is entombed, granted immortality, because real people with egos and institutional power elect to valorize, preserve, and sustain it.

But Stephen is not in favor with the high priests. He is reduced to an attendant, a suppliant, in their temple. He must bow and scrape to beg George Russell to deliver Deasy's letter to the editor of the Irish Homestead. He must say his own views "superpolitely" (152). He must watch silently as rivals are promoted above him ("They make him welcome" [162], he thinks when his companion and antagonist Buck Mulligan enters). And always, he must offer his submission and deference - "Flatter. Rarely. But flatter," he thinks, as he works a gratifying allusion to Eglinton's work into his speech and watches the older man's face "quick with pleasure, look[] up shybrightly" (171).

The play within the play, then, is more than a pretext for Stephen to deliver a reading of Shakespeare that sheds light on the novel in which it is implanted. Let us return for a moment to Lyster's characterization of Goethe on Shakespeare at the opening of the chapter: "A great poet on a great brother poet." Stephen argues that for Shakespeare, brothers are rivals and usurpers. Poets are opportunistic sellouts, willing to curry favor with those in power if it might lead to a consolidation of their worldly position. What, then, are great poets?

Stephen's Shakespeare is a man whose late tragedies are fueled by crisis and misery: grief at the loss of his son, bitterness at the unfaithfulness of his wife with his own brother. But he is also a contriver, a chancer, a man without scruples in near single-minded pursuit of social and financial gain. As Stephen puts it, "his 
name is dear to him, as dear as the coat and crest he toadied for" (172). The bard, he alleges, is "lead[] astray" by "the sense of property" (168):

He drew Shylock out of his own long pocket. The son of a maltjobber and moneylender he was himself a cornjobber and moneylender, with ten tods of corn hoarded in the famine riots. [...] He sued a fellowplayer for the price of a few bags of malt and exacted his pound of flesh in interest for every money lent. How else could Aubrey's ostler and callboy get rich quick? All events brought grist to his mill. Shylock chimes with the jewbaiting that followed the hanging and quartering of the queen's leech Lopez [...] Hamlet and Macbeth with the coming to the throne of a Scotch philosophaster with a turn for witchroasting. The lost armada is his jeer in Love's Labour Lost. His pageants, the histories, sail fullbellied on a tide of Mafeking enthusiasm. (168)

The keen instinct that turns his art like a sail in response to the winds of his royal patrons' whims, and every transaction to his own advantage - from whence is this born? Stephen gives no account. The elision is all the more curious, since Shakespeare's biographer George Brandes, who is cited by Stephen throughout the episode, states explicitly that "it was [Shakespeare's] constant ambition to restore the fallen fortunes of his family” (Brandes 1898, 166), after seeing his father imprisoned for debt and stripped of his position as Alderman in his youth (12). According to Brandes, Shakespeare "never for a moment lost sight of Stratford, and [...] had no sooner made a footing for himself in London than he set to work with the definite aim of acquiring land and property in the town from which he had gone forth penniless and humiliated. His father should hold up his head again, and the family honour be re-established" (15).

The missing explanation in Stephen's fiction of Shakespeare is not omitted from Joyce's fiction of Stephen. The young poet's hardships due to his father's financial troubles are detailed in A Portrait of the Artist as a Young Man. ${ }^{3}$ His debts to friends and acquaintances are enumerated meticulously throughout Ulysses. In this episode alone, he notes the pound lent to him by Russell (Joyce 1986, 155), the two shillings by Fred Ryan (176), and the boots by Mulligan, to whom he owes an additional nine pounds: "His boots are spoiling the shape of my feet" (173), he thinks, looking down midway through this performance. "Buy a pair. Holes in my socks. Handkerchief too" (173). Financial need permeates the performance in the library, which ends not with a discussion of the intellectual or aesthetic merits of the theory but with the elders' ruling that Stephen shall extract neither profit nor fame from it. "I don't see why you should expect payment for it," chides Eglinton, ending their exchange on a note of personal insult: "You are the only contributor to Dana who asks for pieces of silver. Then I don't know about the next number. Fred Ryan wants space for an article on economics” (176). If Stephen's performance had been pitched at selling

3 For a discussion of the significance of these hardships, see Hepburn Fall 2004-Summer 2006, 197218.

4 For an extended analysis of the relation between Stephen's debts and his reading of Shakespeare's usury, see Osteen 1995, 214-227. 
himself or his theories to this audience, it has clearly flopped - not because of the value of the ideas themselves, but because his reputation as a debtor has removed him from social recognition, just as it removed his own father and Shakespeare's father before him.

Critics rarely draw attention to these aspects of the situation in which Stephen deploys his portrait of Shakespeare. The episode is read primarily as a guide to interpreting Ulysses as a work of art in which Joyce places himself as both father and son. The key is presumably given in the climax of Stephen's performance, which brings together his claim that Shakespeare imprints the incidents of his life's drama upon his plays with a quasi-Sabellian view of Trinitarian being. This highly abstract theory of creation holds that the poet, like the divine "Father [who] was Himself His Own Son" (171), sublimates himself above and beyond needing others and ultimately becomes one with himself through this creation: "We walk through ourselves, meeting robbers, ghosts, giants, old men, young men, wives, widows, brothers-in-love, but always meeting ourselves" (175). The fictional frame in which this mystical theory of art is embedded, however, reinscribes Stephen within the earthly tragedy of an alienated, dispossessed figure, even as he asserts his aspirations to rise above his situation through the performance that articulates it. Stephen finds exiled heroes everywhere because he is excluded from the inner circle he dreams of entering. He is not in tune with the intellectual fads of his time. He likes Aristotle and not Plato. He has holes in his socks. Lonely, stricken by poverty-consciousness, he seeks an abstract ghostly father within himself because he cannot connect to his own. His reading of Shakespeare is confirmation of his own orphanhood and alienation, even as it attempts to transcend it.

Stephen's articulation of his theory of creation is immediately preceded by the strangest tangent in his entire performance. Fatherhood, he abruptly declares after noting that Shakespeare wrote Hamlet in the months after his father's death, is "founded [...] [u]pon uncertitude, upon unlikelihood" (170). Paternity is but "a legal fiction" (171). There is no paternal correlate to the undeniable physical bond of mother and child - a father only knows himself to be a father by his marriage certificate. Fathers and sons are forever "sundered by a bodily shame" (171), the shame of their disconnection. All sons, in the end, are rivals to and usurpers of their fathers. Stephen's disjointed and obsessive rant culminates in his claim that the fundamental leitmotif of Shakespeare's work is the unfaithful wife who renders her husband's paternity unsure. What connects this sudden digression on paternity, which erupts seemingly out of nothing, and the aforementioned context for his lecture in the library? Protection and survival, once again. No father will protect the child born out of wedlock. But even the rightful heir is separated from the alienation and displacement of the bastard by the avowal of the father. Denying the defenselessness of the child in the face of the father's whim, Stephen seeks to find the means of security and self-creation in his own solipsistic imagination. Publicly, he announces that "[f]atherhood, in the sense of unconscious begetting, is unknown to man" 
(170). But inwardly, what he finds unknowable in himself is the fact of his own vulnerability and dependence upon a father who is merely human.

Something that the character does not want to know, to own about themselves: this is the dark seed that unfurls into the flower of poetic criticism in both of these novels. In Joyce and in Goethe, we find a character thinking about a character thinking about a character: a character (Stephen Dedalus) who creates a character (Shakespeare) who creates a character (Hamlet) who stages a play that mirrors his own situation. In each case, as Stephen himself intimates, the creation of character is a strategy to overcome a block. The character within the frame of fiction is under an unacknowledged threat or pressure of existence. He seeks to protect himself and to advance his aims in and through this act of critical reinvention and artistic imagination. Yet within the act there remains a trace of the fatal block: the impossibility or as we might call it, the necessary fictionality - of overcoming it. The peculiar power and magnetism of these scenes of poetic criticism derives in part from the inner conflict of the character that galvanizes the act of criticism, spurring the character on to generate an ever more elaborately ramified re-presentation of the conflict, and prolonging the energy of grappling with its equivocal consequences. As we shall see in Coetzee's Elizabeth Costello, the final instance of poetic criticism we shall analyze, this structure of intensification gives rise to a kind of metafictional echo. The character returns ultimately to themselves in the form of the other-self of their invented fiction.

\section{Coetzee}

In the lecture hall of a small American college, a novelist from Australia mounts the podium and unfolds her notes. Her argument meanders, confusing her listeners. Each gesture is obliquely self-canceling. She declares herself obsessed with the immortality of her books, yet notes that the great libraries of the world that hold them will one day “"crumble and decay”" (Coetzee 2003, 17). She evokes Kafka's ape, whose performance she views as a kind of “'test,"” “"an examination, a viva voce,” but she denies that she too is a speaking ape before an academy (18). Repeatedly she tests her authority to say what the text of Kafka's “A Report to an Academy” means, and then just as abruptly withdraws it: "That is not the point of the story, say I, who am, however in no position to dictate what the point of the story is"” (19). By way of conclusion, she expresses her gratitude for the literary award they have bestowed upon her work, and reminds her audience in the very same breath of the fact that she "will cease to be read and eventually cease to be remembered" (20). The applause begins, tentative at first, then rising. She smiles, savoring the moment. Just as the dean of the college rises to announce the end of the event, a voice interrupts him: "Excuse me! [...] Excuse me! I have a question for the speaker. May I address the speaker?"' $(20-21)$ The novelist does not respond. "Frostily she gazes into 
the distance" (21). The hosts are embarrassed; the would-be questioner, irked. The ceremony ends on a note of awkwardness and discord.

Embedded within the opening episode of J.M. Coetzee's Elizabeth Costello, this scene stages an act of literary criticism that subverts the intended purpose of the occasion. Indeed, the novel's own chapters are provocatively identified as "Lessons," and several of these "Lessons" (including this one) were read aloud by Coetzee in lieu of conventional lectures at academic institutions. The performance of fictions which themselves stage performed acts of criticism, often via lectures by Elizabeth Costello that explicate literary and philosophical texts, raises several questions: the question of what it means to read a text, of what it means to be instructed by one, and, moreover, of what happens when our desire for instruction is supplanted by a work of fiction.

Although Elizabeth Costello is often taken by critics to be a mouthpiece for her author's views and her lectures read as thinly fictionalized accounts of his own ethical stance, the text itself complicates this interpretation by framing her lectures within a narrative that brings into play other conflicts and energies. Costello's performance of the lecture described above is embedded within a narrative of her visit to Altona College. As is also the case with Lessons 3 and 4 of the novel (delivered by Coetzee on the occasion of the Tanner Lectures at Princeton University, and later published separately as The Lives of Animals), the frame narrative surrounding the occasion for her talk is largely focalized through the eyes of her son, John. John is a young professor at a college in Massachusetts. His only reason for accompanying his mother on this trip to collect her prize is, he thinks, "simply to protect her" (30). But is that all?

He is here with her, out of love. He cannot imagine her getting through this trial without him at her side. He stands by her because he is her son, her loving son. But he is also on the point of becoming - distasteful word - her trainer.

He thinks of her as a seal, an old, tired circus seal. One more time she must heave herself up on to the tub, one more time show that she can balance the ball on her nose. Up to him to coax her, put heart in her, get her through the performance. (3)

It is, in John's mind, a play in several acts: dinner with the jury, an interview, a radio show, an awards ceremony, and an acceptance speech. He is present for all of them as a minor character, albeit as her loving and supportive son. Yet the allusion in this passage to his role as a "trainer" recalls the trainer of Red Peter in Kafka's story. The role is not without its occupational hazards. As Red Peter recalls, his first trainer, driven insane by the spectacle of the ape's self-flagellation, "soon gave up teaching, and had to be carted off to a mental hospital” (Kafka 1993, 292).

Elizabeth Costello begins her speech about Kafka's "Report” by reminding her audience of its poetic form: "'If you know the story, you will remember that it is cast in the form of a monologue, a monologue by an ape. Within this form there is no means for either speaker or audience to be inspected by an outsider's eye"' (Coet- 
zee 2003, 18). Her refusal of the would-be interlocuter's question at the end of her speech reminds us that her appearance, too, is staged as a monologue. Kafka, in fact, composes several incomplete draft versions of "A Report to an Academy," in which he experiments with focalizing the narrative from various points of view: the point of view of an anonymous visitor to Red Peter, of an audience member who has just witnessed one of his performances, and of Red Peter's trainer, "an honorary doctor of great universities" (Kafka 2005, 259). All of these spectatorial perspectives on Red Peter - the audience member, the trainer, the visitor - fall away in the final version of “A Report.” Red Peter speaks in the first person throughout Kafka's text, in which no other voices are heard. ${ }^{5}$

In contrast, Elizabeth Costello's utterances are staged within a narrative that is focalized largely from the "'outsider's eye'” (Coetzee 2003, 18), furnished in this episode by her son's point of view. His perspective on his mother is notably ambivalent. There is, of course, blind loyalty and gratitude for having been given life, for having been kept alive by his parent when he was at his most vulnerable and dependent. But there are also memories of abandonment, neglect, and rejection:

For as far back as he can remember, his mother has secluded herself in the mornings to do her writing. No intrusions under any circumstances. He used to think of himself as a misfortunate child, lonely and unloved. When they felt particularly sorry for themselves, he and his sister used to slump outside the locked door and make tiny whining sounds. In time the whining would change to humming or singing, and they would feel better, forgetting their forsakenness. (4)

Like Red Peter's choice to seek a way out of his captivity, Elizabeth Costello's choice to seek transcendence through art, to devote her life to courting the acceptance and applause of the academy, is a choice that involves strategy, performance, and - at least from her own child's point of view - a betrayal of natural bonds. His memories of his mother's working life are colored by pain. Yet he recalls that as he and his sister's lamentations proceed from animal whining to human singing, their anguish abates. What takes the place of pain is voice: voice that proceeds from a kind of loneliness, just as in Kafka's story. ${ }^{6}$ This voice even develops until the point that John joins the author within her innermost sanctum. The passage above continues:

Now the scene has changed. He has grown up. He is no longer outside the door but inside, observing her as she sits, back to the window, confronting, day after day, year after year, while her hair slowly goes from black to grey, the blank page. What doggedness, he thinks! She deserves

5 For an extended discussion of the significance of the monologic voice of "A Report," see Ong 2016, $220-230$.

6 Red Peter describes the utterance of his first words in human language as the moment at which he enters into human society: "And then what a victory it was both for him and for me when one evening in front of a large group of spectators [...] I curtly exclaimed 'Hey!' breaking out in human sounds, plunging into human society with that cry, and feeling its echo, 'Listen, he's talking!' like a kiss over my entire sweat-soaked body.” (Kafka 1993, 291) 
the medal, no doubt about that, this medal and many more. For valour beyond the call of duty. (4-5)

In this change of scene, John places himself beside the writer, his mother, but also in a sense above her, in the position of a judge who can say what she deserves. He has become, in other words, a critic: one who endows her labor with value and significance. The motif repeats throughout the narrative. At her radio show, he watches from "the control booth" (11); he defends her to the critic Susan Moebius, offering his own interpretation of her work; in the airport, he questions his mother, in what is the final interview of the visit, about the meaning of her lecture.

His efforts to understand her are also, as the locus of his perspective in the control booth suggests, attempts to rewrite her from his own point of view: to see her in a way in which she cannot see herself, to know her. But why? In his own mind, he has come with her on this visit in order to protect her from the academics, the journalists, and the critics who seek to grasp the secret at the heart of her work. They dissect her utterances, invade her privacy, and continually bait her to reveal her personal opinions and private experiences. Costello herself is adept at evading them: "Her strategy with interviewers is to take control of the exchange, presenting them with blocks of dialogue that have been rehearsed" (9). She controls the highly scripted version of her authorial persona that is available for public consumption. "She can come home with her true self safe," John thinks as they prepare to leave the college, "leaving behind an image, false, like all images" (30).

When the critic Susan Moebius goes so far as to question John in bed about his mother after she seduces him - "Research: will that be her name for it afterwards? Using a secondary source?" he thinks as they kiss in the hotel elevator (24) - he allows himself to entertain the thought that perhaps his mother's authorial control over her image is an illusion to protect her from the knowledge of what she is "really like":

\footnotetext{
What is the truth of his mother? He does not know, and at the deepest level does not want to know. He has opinions of his own, but he will not speak them. This woman, he would say if he were to speak, whose words you hang on as if she were the sibyl, is the same woman who, forty years ago, hid day after day in her bedsitter in Hampstead, crying to herself, crawling out in the evenings into the foggy streets to buy the fish and chips on which she lived, falling asleep in her clothes. She is the same woman who later stormed around the house in Melbourne, hair flying in all directions, screaming at her children, 'You are killing me! You are tearing the flesh from my body!' (He lay in the dark with his sister afterwards, comforting her while she sobbed; he was seven; it was his first taste of fathering.) This is the secret world of the oracle. How can you hope to understand her before you know what she is really like? (30-31)
}

Throughout the episode, John has described himself as his mother's creation (“'Out of her very body I came, caterwauling,"” he declares to Susan, “'[f]lesh of her flesh, blood of her blood" [28]) and his mother's character (for "[h]e is in her books, or some of them" [5]). In this moment, however, he shows that he too has a certain au- 
thorial power: a capacity to produce this other, rival image of his mother. Subverting his mother's image with his own perspective on her, he strips her of "her lady novelist's uniform" (4), her scripted ease, her sphinx-like mystery and invulnerability. The divine author has a mortal body that is exhausted, in need; a body from which flesh can be torn, and in which fear of dying and rage at being consumed by the needs of other bodies resides. Yet this power over his mother, the power to reenvision her, comes at a cost. The sacred myth of mother love (what Stephen Dedalus calls "the only true thing in life" [Joyce 1986, 170]) is destroyed by John's recollections. What emerges in its place is a raging, self-centered, wounded, limited, and neglectful mother. What can she tell John of his own value and importance? Is he waiting faithfully for his mother to finally receive the recognition she craves, so that she can at last turn to him and love him?

The ambivalence of her son's desire - on the one hand, to recognize his mother's vulnerability and need, and, on the other hand, to mask it by presenting her to the world (and even to himself) as a renowned novelist whose sole ambition is immortal fame - suggests that the dynamics underlying the reception of these interpretive performances are equally at stake in their fictional representations. At the end of her visit, John accompanies his mother on the flight home:

She lies slumped deep in her seat. Her head is sideways, her mouth open. She is snoring faintly. Light flashes from the windows as they bank, the sun setting brilliantly over southern California. He can see up her nostrils, into her mouth, down the back of her throat. And what he cannot see he can imagine: the gullet, pink and ugly, contracting as it swallows, like a python, drawing things down to the pear-shaped belly-sac. He draws away, tightens his own belt, sits up, facing forward. No, he tells himself, that is not where I come from, that is not it. (Coetzee 2003, 33-34)

As their bodies descend, spiraling, to the ground, John's body is momentarily oriented between the western sun to his left and his mother's body to east. The scene recalls Kant's essay "What does it mean to orient oneself in thinking?” (1786), in which the very possibility of cardinal orientation (and hence of the intelligibility of the world to us) is grounded in a felt bodily intuition of the difference between the right and left sides of one's body.

In the proper meaning of the word, to orient oneself means to use a given direction [...] in order to find the others - literally, to find the sunrise. Now if I see the sun in the sky and know it is midday, then I know how to find south, west, north, and east. For this, however, I also need the feeling of a difference in my own subject, namely the difference between my right and left hands. I call this a feeling because these two sides outwardly display no designatable difference in intuition. If I did not have this faculty of distinguishing, without the need of any difference in the objects, between moving from left to right and right to left and moving in the opposite direction and thereby determining a priori a difference in the position of the objects, then in describing a circle I would not know whether west was right or left of the southernmost point of the horizon, or whether I should complete the circle by moving north and east and thus back to the south. Thus even with all the objective data of the sky, I orient myself geographically only through a subjective ground of differentiation; and if all the constellations, though keeping the same shape and position relative to one another, were one day by a miracle to be reversed 
in their direction, so that what was east now became west, no human eye would notice the slightest alteration on the next bright starlit night, and even the astronomer - if he pays attention only to what he sees and not at the same time to what he feels - would inevitably become disoriented. (Kant 1998, 4-5)

Kant's mention of the "astronomer" who "become[s] disoriented" from having lost the feeling of his own body sheds light on the figure of John, an "assistant professor of physics and astronomy," who earlier on in this Lesson loses his sense of orientation when navigating the corridors of the hotel (Coetzee 2003, 60). Now, as he glimpses the body of his own mother beside him, he is disgusted by a vision of the snakelike innards of his origin. He denies what the poet Allen Grossman calls in his reading of Kant's text "the perishing basis of our common life, our corporeal singularity, our physical subject nature, our body as it is the bearer of recognition and intelligibility" (Grossman 2009, 8): the basic form of pre-cognition that is his birthright, and with it the (re)cognition of the embodied condition of his mind.

At the same time, it is not bodily intuition that gives him this vision of his mother, but imagination. To imagine what she is like inside mirrors what an author would do to a character, and indeed what critics have tried to do to Elizabeth Costello throughout her visit in an attempt to understand her works. The scene thus emphasizes a theme that we have seen already to varying degrees in Goethe and Joyce. A character who seeks to interpret a fictional character, to master the work of art in which the fictional character is embedded, is eventually driven to decipher the mystery of the author. ${ }^{7}$ Coetzee's text amplifies the mutual entanglement of these different positions, insofar as it takes the form of a novel bearing the same title as the name of its main character, who is a novelist, and whose son bears the same first name as the author of the novel in which he appears as a character. The son becomes a critic of his mother, in whose body he literally came to life, and of her novels, in which he figures as a character; he is, as he thinks in another episode, "written into her books in ways that he sometimes finds painful" (Coetzee 2003, 60). But as the scene on the flight suggests, John's imaginative reconstruction of his mother-and-author's life ends in sudden, involuntary recoil. He is torn between the desire to know his mother and an almost instinctive urge to deny this knowledge. He does not seem to want to acknowledge that knowing Elizabeth Costello amounts, in the last analysis, to knowing himself.

In different ways, each of these texts invite us to understand acts of poetic criticism as bound up with the search for an indirect dialogue, a form of existential selfexamination, in which the encounter with another work of art becomes an occasion for reading the self. Every attempt at self-knowledge, however, also belies an attempt to hide or refashion the self. Whereas Schlegel's idea of poetic criticism emphasizes

7 Describing the process by which he interpreted Hamlet, Wilhelm Meister declares: ““An actor, on the other hand, must be able to account for his praise or disapproval of a play. And how is he to do that if he does not penetrate to the author's mind and intentions?’” (Goethe 2016, 499) 
the creative power of the author to reshape and represent a work of art within their own creation, these fictions of poetic criticism cut against a certain ideal of mastery. The disowning or displacement of what belongs to these characters surfaces again and again in each of these scenes. Wilhelm approaches his condition of passivity and ineffectuality through Hamlet, but at the same time lays emphasis on Hamlet's inherent aristocratic identity, burying his own dilemma over how to take on the impossible task of becoming noble. Similarly, Stephen Dedalus reimagines a Shakespeare whose opportunism and ambition matches his own. At the same time, he represses the shame of the son at his father's failure, and the impossibility of knowing himself in the absence of his father. Elizabeth Costello attempts to own her impossible relation to reality by enacting the performance of Kafka's ape, but she leaves out the fundamental motive at the heart of Red Peter's narrative - namely, the adoption of a purely performative identity that drives him nearly insane in order to avoid ending up dead or imprisoned. The inner conflict at play for each character cannot be resolved in the imaginative attempt to revivify another work of art. It must be lived out, not thought out, in each of these character's lives, as other events beyond their control and beyond the domain of their intellectual and artistic efforts become nodes for its refraction, resolution, and reawakening. At the same time, the paradox at the heart of each character's conflict has a dynamic energy that carries throughout the plot, permeating the character system and inflecting events that lie outside any one person's locus of agency. The novel represents what appears to be a conflict that is internal to one character as formative of a whole world: a rival world, in which the conflict and reconciliation of mutually exclusive aims that would otherwise not be legible within the reality surrounding it can be staged.

Many other resonances between these episodes emerge from their juxtaposition. Each of these figures are, in distinct ways, spurred by a sense of loneliness, alienation, and a lack of attunement to the values of the world in which they live. They share a powerful sense of wanting to be known, recognized, valued, and even loved in spite of this alienation. Neither Goethe, Joyce, nor Coetzee attempt to ironize this impulse - on the contrary, it is the force of this longing that brings these characters face to face with the possibility of non-being or meaninglessness when confronting the other, and that gives rise to the concurrent desire for control over how they are to be understood by others. The interplay between the authoritative, disembodied voice of criticism and the emergence of the character's body into a public realm that is conditioned by socioeconomic forces is hence foregrounded in the staging of each of these performances of poetic criticism. What is at stake in these scenes appears to be a very difficult and painful form of self-knowledge that has to be highly protected by the mediation of art - almost as if the more wounding the knowledge, the more layers of protection must be marshaled to bring it into the world. The exposure of vulnerability and lack of control within these narratives is bound up with the dialectical relation between authorial and characterological modes of being, between the one who controls all and suffers nothing and the one who controls nothing and suffers all. This relation in turn highlights the intractable problem of finding a 
way to live with powerlessness, contingency, commonness, suffering, and meaninglessness.

Ultimately, however, I am less interested in developing a general theory or account of the significance of poetic criticism than in taking seriously the idea that a conceptual definition might miss the manner of its embodiment within the fictional text. Why do we read these fictions? What, in the end, do we want from them? In staging acts of poetic criticism, Goethe, Joyce, and Coetzee pose the question of what it means to encounter a work of art, of what it means to be a reader. To fully respond to this question, it becomes necessary to create another work of art. This other fiction - a 'poetic' fiction in Schlegel's sense - highlights the tension between three interwoven fields of representation: the work of art that is encountered, the fictional interpretation generated by the character encountering it, and the fictional life of the character in which this encounter is embedded. In the interplay of these representations, the reader is caught. For, as these works of poetic criticism reveal, the ego of the fictional reader/critic both spurs the work of criticism and is the block to understanding the work of art to which the critic is exposed. The narratives in which these acts of criticism are embedded underscore the energies of the critic's ego in enabling and limiting the act of criticism, in part by narrating the conditions under which the fictional critic submits to suffering alongside the character whom they read while simultaneously developing various forms of self-protection to cope with their difficulties in reality. To expose oneself to a work of poetic criticism, then, is to be radically disarmed, undefended against the needs of a fictional character in confronting a work of art. Is this what we desire of art? Of criticism? As Toril Moi puts it, works of art demand acts of acknowledgment that "reveal us: who we take ourselves to be, how we picture our relationship to the other" (Moi 2017, 207) and, crucially, how we may fail in our attempts to respond to the other. "I write criticism to find out about myself," claims Michel Chaouli, "including about the limits of my cognitive and affective resources” (Chaouli 2013, 333). Intimacy with a work of art involves openness to exposing one's limits in the encounter. The fiction of poetic criticism yields a form in which these attempts and limits meet. In so doing, they give rise to yet another work of art. $^{8}$

\section{Bibliography}

Brandes, George. William Shakespeare: A Critical Study. Vol. 1. New York: The Macmillan Company, 1898.

Chaouli, Michel. “Criticism and Style.” New Literary History 44.3 (2013): 323-344.

Coetzee, J.M. The Lives of Animals. Princeton: Princeton University Press, 1999.

8 I thank Philip Fisher, Michel Chaouli, Jan Lietz, and the participants in the Conference on Poetic Critique - especially Jeff Dolven, Eli Friedlander, Amanda Goldstein, and Dennis Tenen - for their generous comments on earlier versions of this essay. 
Coetzee, J.M. Elizabeth Costello. New York: Penguin Group, 2003.

Gifford, Don, and Robert J. Seidman. Ulysses Annotated: Notes for James Joyce's Ulysses. Berkeley: University of California Press, 2008.

Goethe, Johann Wolfgang von. Wilhelm Meister's Apprenticeship. The Essential Goethe. Ed. Matthew Bell. Princeton: Princeton University Press, 2016. 371-749.

Grossman, Allen. "Poetry and Enlightenment (Kant on Orientation, Whitman on the Brooklyn Ferry, Celan on the Meridian)." True-Love: Essays on Poetry and Valuing. Chicago: University of Chicago Press, 2009. 1-14.

Hepburn, Allan. "A Portrait of the Artist as a Young Man and Poverty." James Joyce Quarterly 42/43 (No. 1/4: Fall 2004-Summer 2006): 197-218.

Joyce, James. Ulysses. Ed. Hans Walter Gabler. New York: Random House, 1986.

Kafka, Franz. "A Report for an Academy." The Metamorphosis, In the Penal Colony, and Other Stories. Trans. Joachim Neugroschel. New York: Simon \& Schuster, 1993. 284-285.

Kafka, Franz. "A Report to an Academy: Two Fragments." The Complete Short Stories. Ed. Nahum N. Glatzer. London: Vintage Books, 2005. 259-262.

Kant, Immanuel. "What Does It Mean to Orient Oneself in Thinking?" Religion within the Boundaries of Mere Reason and Other Writings. Trans. and Eds. Allen Wood and Giorgio di Giovanni. Cambridge, UK: Cambridge University Press, 1998. 1-14.

Moi, Toril. Revolution of the Ordinary: Literary Studies after Wittgenstein, Austin, and Cavell. Chicago: University of Chicago Press, 2017.

Moretti, Franco. The Way of the World: The Bildungsroman in European Culture. Trans. Albert Sbagria. London: Verso, 1987.

Norman, Judith. "Literary Criticism in the Age of Critical Philosophy." Brill's Companion to German Romantic Philosophy. Eds. Elizabeth Millán Brusslan and Judith Norman. Leiden: Brill, 2018. 195-216.

Ong, Yi-Ping. "Lectures on Ethics: Kafka and Wittgenstein." Wittgenstein and Literary Modernism. Eds. Karen Zumhagen-Yekplé and Michael LeMahieu. Chicago: University of Chicago Press, 2016. 206-230.

Osteen, Mark. The Economy of Ulysses: Making Both Ends Meet. Syracuse: Syracuse University Press, 1995.

Pirholt, Mattias. Metamimesis: Imitation in Goethe's Wilhelm Meisters Lehrjahre and Early German Romanticism. Rochester, NY: Camden House, 2012.

Schlegel, Friedrich. "On Goethe's Meister." Classic and Romantic German Aesthetics. Ed. J.M. Bernstein. Cambridge, UK: Cambridge University Press, 2003. 269-286.

Wilkinson, Elizabeth M., and L.A. Willoughby. "Having and Being, or Bourgeois versus Nobility: Notes for a Chapter on Social and Cultural History or for a Commentary on Wilhelm Meister." German Life and Letters 22.1 (October 1968): 101-105. 